\title{
ОСОБЕННОСТИ ГРУНТОВ И ПОТЕНЦИАЛ ВОССТАНОВЛЕНИЯ ПРИРОДНО-ТЕХНИЧЕСКОЙ СИСТЕМЫ «ХВОСТОХРАНИЛИЩЕ ЕВРАЗ КГОК»
}

\author{
Меньшикова Елена Александровна ${ }^{1}$, \\ menshikova_e@list.ru
}

\author{
Караваева Татьяна Ивановна 1 , \\ jewel_@list.ru
Хайрулина Елена Александровна 1 , elenakhay@gmail.com

\author{
Митракова Наталья Васильевна', \\ mitrakovanatalya@mail.ru \\ 1 Пермский государственный национальный исследовательский университет, \\ Россия, 614990, г. Пермь, ул. Генкеля, 4.
}

\begin{abstract}
Актуальность. Природно-технические системы, формирующиеся в горнодобывающих районах, являются объектами повышенного экологического внимания в связи со значительным техногенным преобразованием всех компонентов природной среды. Состояние техногенного ландшафрта среди прочих составляющих определяется свойствами литогенного ресурса, которым для территорий горной добычи выступают многотоннажные отходы - породы вскрыши и отходы обогащения полезных ископаемых.

Целью настоящей работы является оценка почвенно-экологического потенциала техногенных грунтов природнотехнической системы хвостохранилища Качканарского горно-обогатительного комбината («Хвостохранилище EBPAЗ КГОК») и выявление перспектив развития экосистем и потенциала их самовосстановления.

В задачи исследований входило: установление признаков почвообразования и определение основных агрохимических и экологических характеристик техногенных грунтов, представленных хвостами мокрой магнитной сепарации, оценка их фитотоксичности; оценка состояния растительного покрова; выявление необходимости проведения рекультивационных работ.

Объект исследования - техногенные грунты, являющиеся частью литогенной основы природно-технической системы «Хвостохранилище ЕВРАЗ КГОК».

Методы. Исследование техногенных грунтов выполнялось на участках их выноса за пределы хвостохранилища. Полевые исследования включали: общее маршрутное знакомство с территорией; полевое изучение почв и техногенных грунтов, отбор образцов; изучение растительного покрова территории. Лабораторные исследования проведены в специализированных лабораториях с применением унифицированных методик. Содержание микроэлементов определяли методом ICP-MS.

Результаты. Хвосты мокрой магнитной сепарации с позиций почвоведения диагностированы как техногенные поверхностные образования группы артисрабрикаты, подгруппы артииндустраты. По сравнению с фоновыми почвами они характеризуются меньшим содержанием органического вещества, общего азота, менее кислой реакцией почвенного раствора, по содержанию водорастворимых ионов являются незасоленными, характеризуются допустимым уровнем загрязнения элементами 1-2 классов опасности и отсутствием острого токсического действия на исследуемые тест-системы. Активное протекание лесовосстановительных процессов на техногенных поверхностных образованиях и удовлетворительное состояние растительности демонстрируют отсутствие негативного воздействия указанных отложений на растительность. Вслед за восстановлением растительности в них появляются признаки начального почвообразования - образование лесной подстилки, накопление органического вещества и начальная дифрференциация почвенных горизонтов. Почвенно-экологическое состояние исследуемой природно-технической системы признано удовлетворительным, не требующим в настоящее время проведения специальных природоохранных мероприятий по восстановлению почвенного и растительного слоя на участках техногенных поверхностных образований.
\end{abstract}

\section{Ключевые слова:}

Хвостохранилище, техногенные грунты, почвы, техногенные поверхностные образования, растительный покров, оценка состояния, почвенно-экологическое состояние, природно-техническая система, техногенные ландшасрты.

\section{Введение}

Природно-технические системы, формирующиеся в горнодобывающих районах, являются объектами повышенного экологического внимания в связи со значительным техногенным преобразованием всех компонентов природной среды. Включаясь в природную среду, технические системы становятся источниками воздействия, в разной степени влияющими на процессы, протекающие в естественной части [1], создавая особый вид систем - природно-технические системы [2]. В соответствии с выделенными
Г.К. Бондариком структурными уровнями [3], природно-техническую систему «Хвостохранилище» можно определить как элементарную [4], компонентами которой являются отдельное сооружение - хвостохранилище, и сфера его взаимодействия с окружающей природной средой.

Создание хвостохранилищ, площадь которых исчисляется десятками квадратных километров, сопровождается полным уничтожением почвеннорастительного покрова в их границах. Значительная часть нарушенных территорий в течение многих де- 
сятилетий по различным причинам сохраняет облик техногенной пустыни и влечет за собой соответствующие негативные последствия в почвенноэкологическом, геоботаническом, общеэкологическом и санитарно-гигиеническом планах [5-8], особенно в случае складирования в хвостохранилище токсичных отходов [9-12].

В результате складирования хвостов обогащения формируется комплекс техногенных отложений, который постепенно начинает выполнять функции почвы и определяет условия обитания живых организмов [13], прежде всего, растительности. Техногенные грунты, частично функционирующие как обычные почвы, являются объектами почвенных классификаций и рассматриваются в почвоведение в качестве техногенных поверхностных образований (ТПО) [1416]. Зональные различия в строении ТПО не проявляются. Морфологические и химические свойства ТПО определяются технологическим фактором (особенностями производства, свойствами техногенных субстратов, способом заполнения). ТПО хвостохранилищ в почвенной классификации отнесены к группе артифабрикатов, подгруппе артииндустратов [14].

Особенности эволюции почв, формирующихся на техногенных поверхностных образованиях в горнодобывающих районах, изучены В.А. Андрохановым [5]. Установлено, что восстановление почв происходит путем последовательной смены фаз почвообразования, каждая из которых соответствует определенному типу эмбриоземов (слаборазвитых примитивных почв на техногенных и природных грунтах) и сингенетично связана со стадией развития растительной сукцессии - последовательной закономерной сменой растительных сообществ.

Начальные стадии развития почвообразовательных процессов в техногенных ландшафтах характеризуются четырьмя основными типами эмбриоземов: инициальные, органо-аккумулятивные, дерновые, гумусово-аккумулятивные. Со стадиями растительной сукцессии происходит эволюция инициальных эмбриоземов с пионерными растительными группировками в органо-аккумулятивные с простыми группировками, затем в дерновые, характеризующиеся сложными растительными группировками, и далее в гумусово-аккумулятивные с замкнутым фитоценозом [17-20]. Чем выше скорость прохождения стадий растительной сукцессии и стадий развития эмбриоземов, тем лучше почвенно-экологическое состояние техногенных ландшафтов [21].

Результаты оценки почвенно-экологических условий техногенно нарушенных территорий в различных природно-географических зонах, содержащиеся в работах $[14,19,21-28]$, свидетельствуют о низких темпах естественного восстановления почвеннорастительного слоя на ТПО хвостохранилищ.

В многолетней динамике восстановления растительности при самозарастании прослеживается постепенное прохождение четырех стадий: инициальной и стадий формирования рудеральных, рудерально-естественных и естественных сообществ. Прохождению этих стадий соответствует увеличение показа- телей видового разнообразия и общего проективного покрытия формирующихся растительных комплексов [26].Часто, несмотря на расположение хвостохранилищ в окружении высокопродуктивных растительных сообществ, на ТПО практически отсутствует растительный покров, на их поверхности могут присутствовать лишь единичные растения, которые в большинстве случаев угнетены [14].

Параллельно с восстановлением растительного покрова под влиянием факторов почвообразования идут процессы формирования молодых почв, гумусообразования и гумусонакопления, на поверхности отмечается дерновый процесс, идет формирование маломощных почвенных горизонтов и их дифференциация, естественное зарастаниеи появление биоты. Все это свидетельствует о начальных процессах естественного восстановления биокомплексов в техногенно нарушенных ландшафтах, которое фиксируется на протяжении 45 и более лет [24].

В большинстве случаев почвенно-экологическое состояние хвостохранилищ признается авторами $[14,19,21]$ неудовлетворительным. Отмечается, что в течение длительного времени (более 30 лет), развитие почвенного покрова соответствует инициальной и органо-аккумулятивной стадиям. Решением проблемы восстановления биологической продуктивности поверхности хвостохранилищ горных предприятий видится рекультивация территорий $[21,23,29-33]$ и создание культурных ландшафтов, а также территорий для научного исследования созданных комплексов [34]. Экологическое восстановление и рекультивационные мероприятия являются комплексной технологией борьбы с загрязнением окружающей среды и экологической реабилитации территорий, которые для таких объектов основываются на фито- и биоремедиации [31, 35] в сочетании с различными прогрессивными физико-химическими инженерными технологиями для достижения наилучших результатов при наименьших затратах [36], применением различных отходов [37-39].

Почва является базисом любой наземной экосистемы, а скорость ее формирования определяет скорость формирования всех других компонентов экосистемы и качество их функционирования. Скорость формирования почвы можно считать параметром, характеризующим почвенно-экологический потенциал техногенного ландшафта, который, в свою очередь, определяется свойствами литогенного ресурса [40].

Целью настоящей работы является оценка почвенноэкологического потенциала техногенных грунтов природно-технической системы хвостохранилища Качканарского горно-обогатительного комбината («Хвостохранилище КГОК») и выявление перспектив развития экосистем и потенциала их самовосстановления.

В задачи исследования входило: установление признаков почвообразования и определение основных агрохимических и экологических характеристик техногенныхгрунтов, представленных хвостами мокрой магнитной сепарации, оценка их фитотоксичности; оценка состояния растительного покрова; выявление необходимости проведения рекультивационных работ. 


\section{Объект исследования}

В качестве объекта исследования рассматриваются техногенные грунты, являющиеся частью литогенной основы природно-технической системы «Хвостохранилище КГОК». Хвостохранилище используется для размещения хвостов мокрой магнитной сепарации, осветления пульпы и сточных вод с последующим включением их в систему оборотного водоснабжения АО «ЕВРАЗ КГОК», осуществляющего добычу и переработку бедных ванадийсодержащих титаномагнетитовых железных руд Гусевогорского месторождения. С учетом классификации (ГОСТ 25100-2020) указанные техногенные грунты относятся к классу дисперсных, подклассу несвязных грунтов антропогенного подтипа.

Сооружения хвостового хозяйства предприятия находятся в границах Качканарского городского округа и административно-территориального образования «Город Лесной» Свердловской области. Добыча руды ведется предприятием с 1963 г. четырьмя карьерами (Главный, Южная Залежь, Западный и Северный) открытым способом по транспортной схеме с внешним отвалообразованием. Добытая в карьерах руда железнодорожным транспортом отправляется на переработку - в цех дробления, и далее на обогатительную фабрику, где подвергается постадийно сухому и мокрому обогащению с получением железованадиевого концентрата, который затем используется для производства готовой продукции - агломерата или окатышей. В ходе обогащения добытой руды на этапе мокрой магнитной сепарации образуются отходы пустой (обедненной) породы - хвосты мокрой магнитной сепарации, размещение которых осуществляется в хвостохранилище.

Хвостохранилище намывное, косогорное, расположено в долинах реки Выи и её правобережного притока - реки Рогалевки. Хвостохранилище состоит их трех отсеков, расположенных каскадом: Рогалевский, Промежуточный, Выйский, с перепадом высот по зеркалу воды в отстойных прудах в направлении с юга на север. По состоянию на конец 2019 г. общая площадь всех отсеков накопителя составляет 19,63 км$^{2}$, объем размещенных в хвостохранилище отходов достигает 949,75 млн м ${ }^{3}$.

По данным инженерно-геологического бурения толща хвостохранилища имеет неоднородное строение, представленное переслаиванием преимущественно песчаной фракции хвостов, а также прослоев техногенных глинистых и крупнообломочных техногенных грунтов различной мощности. Техногенные грунты подстилаются четвертичными делювиальными глинистыми грунтами и аллювиальными песками (от гравелистых до пылеватых), основанием объекта являются породы нижнего силура (пироксеновые порфириты, плагиоклазовые амфиболиты).

Химический состав хвостов (табл. 1) определяется присутствием преобладающих минералов [41]. В частности, основная масса кремнезема, оксидов кальция и магния объясняется существенным (67-78 \%) содержанием в составе хвостов зерен пироксенов соответствующего по составу минерального вида - диопсида
$\mathrm{CaMg}\left[\mathrm{Si}_{2} \mathrm{O}_{6}\right]$. Глинозем в основном присутствует в плагиоклазах и минералах группы эпидота. Железо содержится в эпидоте, амфиболах, гетите и пирите. Из редких элементов наиболее характерны ванадий (в титаномагнетите) и скандий (в пироксенах). Наличие серы связано с присутствием сульфидов, в которых также концентрируются медь, мышьяк, сурьма, свинец, цинк. Хром в основном концентрируется в хромшпинелидах.

Таблица 1. Химический состав хвостов по данным рентгенофлуоресцентного анализа, мас. \%

Table 1. Chemical composition of tailings according to $X$-ray fluorescence analysis, $w t$. \%

\begin{tabular}{|c|c|c|c|}
\hline $\begin{array}{c}\text { Макроком- } \\
\text { поненты } \\
\text { Macro } \\
\text { components }\end{array}$ & $\begin{array}{c}\text { Среднее } \\
\text { содержание } \\
\text { Average } \\
\text { content }\end{array}$ & $\begin{array}{c}\text { Микроком- } \\
\text { поненты } \\
\text { Micro } \\
\text { components }\end{array}$ & $\begin{array}{c}\text { Среднее } \\
\text { содержание } \\
\text { Average } \\
\text { content }\end{array}$ \\
\hline $\mathrm{SiO}_{2}$ & 44,83 & $\mathrm{~V}$ & 0,03 \\
\hline $\mathrm{CaO}$ & 21,14 & $\mathrm{Sr}$ & 0,15 \\
\hline $\mathrm{MgO}$ & 13,85 & $\mathrm{Sc}$ & 0,011 \\
\hline $\mathrm{FeO}$ & 9,82 & $\mathrm{Sn}$ & 0,0085 \\
\hline $\mathrm{Al}_{2} \mathrm{O}_{3}$ & 7,07 & $\mathrm{Ba}$ & 0,0075 \\
\hline $\mathrm{Na}_{2} \mathrm{O}$ & 0,99 & $\mathrm{Cr}$ & 0,0073 \\
\hline $\mathrm{TiO}_{2}$ & 0,786 & $\mathrm{~W}$ & 0,0052 \\
\hline $\mathrm{MnO}_{\mathrm{K}_{2} \mathrm{O}}$ & 0,119 & $\mathrm{Zn}, \mathrm{As}$ & 0,004 \\
\hline $\mathrm{S}$ & 0,056 & $\mathrm{Cu}$ & 0,002 \\
\hline $\mathrm{P}_{2} \mathrm{O}_{5}$ & 0,015 & $\mathrm{Sb}, \mathrm{Ni}$ & $<0,0003$ \\
\hline & & & \\
\hline
\end{tabular}

Хвосты мокрой магнитной сепарации встречаются и за пределами хвостохранилищ. Территория площадью около 280 га к северо-востоку от хвостохранилища представлена техногенно нарушенными землями, на которых условно-естественные почвы были частично смыты и перекрыты слоем рассматриваемых отходов. Массы последних были привнесены на поверхность почвы в 1999 г. в результате аварийного прорыва Восточной дамбы хвостохранилища. Они простираются от Восточной дамбы хвостохранилища преимущественно двумя «рукавами» по тальвегам в направлении р. Выи.

Кроме того, с восточной части хвостохранилища в направлении рек Выи и Большой Медведки разгружаются потоки фильтрационных вод хвостохранилища [42]. Разгрузка сопровождается выносом мелкодисперсной фракции хвостов, в результате чего со стороны дамб Рогалевского и Промежуточного отсеков сформировались участки, представленные техногенными грунтами, площадью 8,6 и 1,9 га, соответственно.

Зональные характеристики экосистем рассматриваемой территории определяются особенностями ее физико-географического расположения. В геоморфологическом отношении территория относится к горно-холмистой зоне Среднего Урала, совпадающей с Приуральской горной грядой, сложенной интрузивными породами основного и ультраосновного состава и продуктами их метаморфизма.

Согласно почвенно-экологическому районированию Российской Федерации рассматриваемая территория расположена в Бореальном географическом поясе Европейско-Западно-Сибирской таежно-лесной 
биоклиматической области, зоне дерновоподзолистых почв южной тайги, Среднеуральской горной провинции. В принятой системе почвенногеографического районирования Свердловской области - в пределах Косья-Исинского почвенного района, входящего в состав одноименного округа Среднеуральской южно-таежной почвенной провинции. В структуре почвенного покрова района ведущее место занимают мозаики горных примитивных почв с горными лесными бурыми и с горными подзолистыми почвами. В естественных условиях в составе почвенного покрова доминируют горные подзолистые почвы с заметным участием горных лесных бурых и примитивных. Ограниченно встречаются горные дерново-подзолистые глееватые и глеевые почвы [43, 44]

Почвенный покров района отличается пестротой, обусловленной высотной поясностью, разнообразием горных пород и сложностью рельефа местности. В естественных условиях почвы на рассматриваемой территории формируются на элювиально-делювиальных отложениях, которые подстилаются массивнокристаллическими породами. Почвы отличаются высокой хрящеватостью и небольшой мощностью.

Рассматриваемая территория относится к СреднеУральскому таежному лесному району таежной лесорастительной зоны. Согласно схеме ботаникогеографического районирования Свердловской области район исследований относится к таежной (хвойно-лесной) зоне, подзоне средней тайги Качканарского округа.

В середине прошлого века в составе лесов данного округа [45] были выделены коренные и производные растительные комплексы. К первым отнесены: сосняки нагорные (IV бонитет) и ельники кисличниковые (III бонитет). Данные группы лесов упорядочены на рассматриваемой площади по высотноорографическому уровню и условиям увлажнения. Сосняки приурочены к наиболее сухим, дренированным возвышенным участкам рельефа; ельники занимают пониженные, свежие и влажные экотопы. Производные растительные комплексы представлены вторичными лесными ценозами, формирующимися в местах нарушения коренной растительности хозяйственной деятельностью. В их составе значительную долю занимают лиственные породы, полное замещение которых хвойными видами происходит на рубеже восьмого/девятого классов возраста древостоя.

Из лиственных древесных пород, выполняющих функции пионеров-освоителей, встречаются береза и осина. Леса местного ареала представлены лиственными лесами с вкраплениями хвойных пород: ели, сосны, пихты, кедра, лиственницы. В травяном покрове преобладают кислица, папоротники, хвощ, брусничник.

\section{Методика исследования}

Исследование техногенных грунтов, которые рассматриваются в почвоведение в качестве ТПО, выполнялось на участках их выноса за пределы хвостохранилища в результате аварийного прорыва дамбы и фильтрационной разгрузки сточных вод в основании дамб хвостохранилища (рис. 1).
Полевые исследования включали: общее маршрутное знакомство с территорией; полевое изучение почв и ТПО, включая заложение и описание почвенных прикопок с определением таксономической принадлежности почв и ТПО; отбор 34образцовдля последующих лабораторных исследований (по ГОСТ 17.4.3.01-2017); изучение растительного покрова территории. Полевые работы по изучению растительности проводились посредством маршрутных наблюдений и рекогносцировочного обследования территории, а также проведением стационарных наблюдений с заложением пробных площадей.

Лабораторные исследования проводились на базе Сектора Наноминералогии «Центра коллективного пользования Пермского государственного национального исследовательского университета», лаборатории гидрохимического анализа геологического факультета ПГНИУ, аналитической лаборатории Пермского НИИСХ ПФИЦ УрО РАН, ФБУЗ «Центр гигиены и эпидемиологии в Пермском крае». Аналитические исследования проведены с применением унифицированных методик. Содержание микроэлементов в пробах почв и ТПО определяли масс-спектральным методом на приборе BRUKER AURORA M90 ICP-MS.

Оценка состояния почв и ТПО проводилась по следующим показателям: агрохимические - содержание органического вещества и общего азота, $\mathrm{pH}$ водной вытяжки и $\mathrm{pH}$ солевой вытяжки, гидролитическая кислотность, емкость катионного обмена, содержание подвижного калия и обменного натрия, нитратный азот; солевая нагрузка с оценкой суммы токсичных солей; техногенная нагрузка-валовое содержание никеля, меди, цинка, свинца, кадмия, мышьяка и ртути; санитарное состояние - острая токсичность ТПО с использованием в качестве тест-объекта Daphnia Magna Straus.

Для определения уровня загрязнения был рассчитан суммарный показатель загрязнения $(\mathrm{Zc})$. В расчет суммарного показателя загрязнения включаются только элементы, содержание которых превышает фоновые показатели (т.е. коэффициент концентрации превышает 1). В качестве фоновых показателей использовались данные по пробам почв, отобранным в условно-естественных условиях вблизи участков, представленных ТПО. По классификации и диагностике почв России (2004) данные почвы относятся к типу бурозем типичный.

\section{Результаты и обсуждение}

Техногенные грунты, распространенные вблизи хвостохранилища АО «ЕВРАЗ КГОК» за счет аварийного прорыва дамбы и фильтрационной разгрузки сточных вод в основании дамб хвостохранилища и представленные веществом хвостов песчаной фракции, идентифицируются по классификации почв 2004 г. и относятся в указанной систематике к техногенным поверхностным образованиям к группе артифабрикаты, подгруппе артииндустраты (рис. 2). Генетические горизонты в отложениях не выражены, гумусовый горизонт, горизонты, характерные для зональных почв (буроземов типичных и горных дерново-подзолистых почв), отсутствуют, почва не сформирована. 


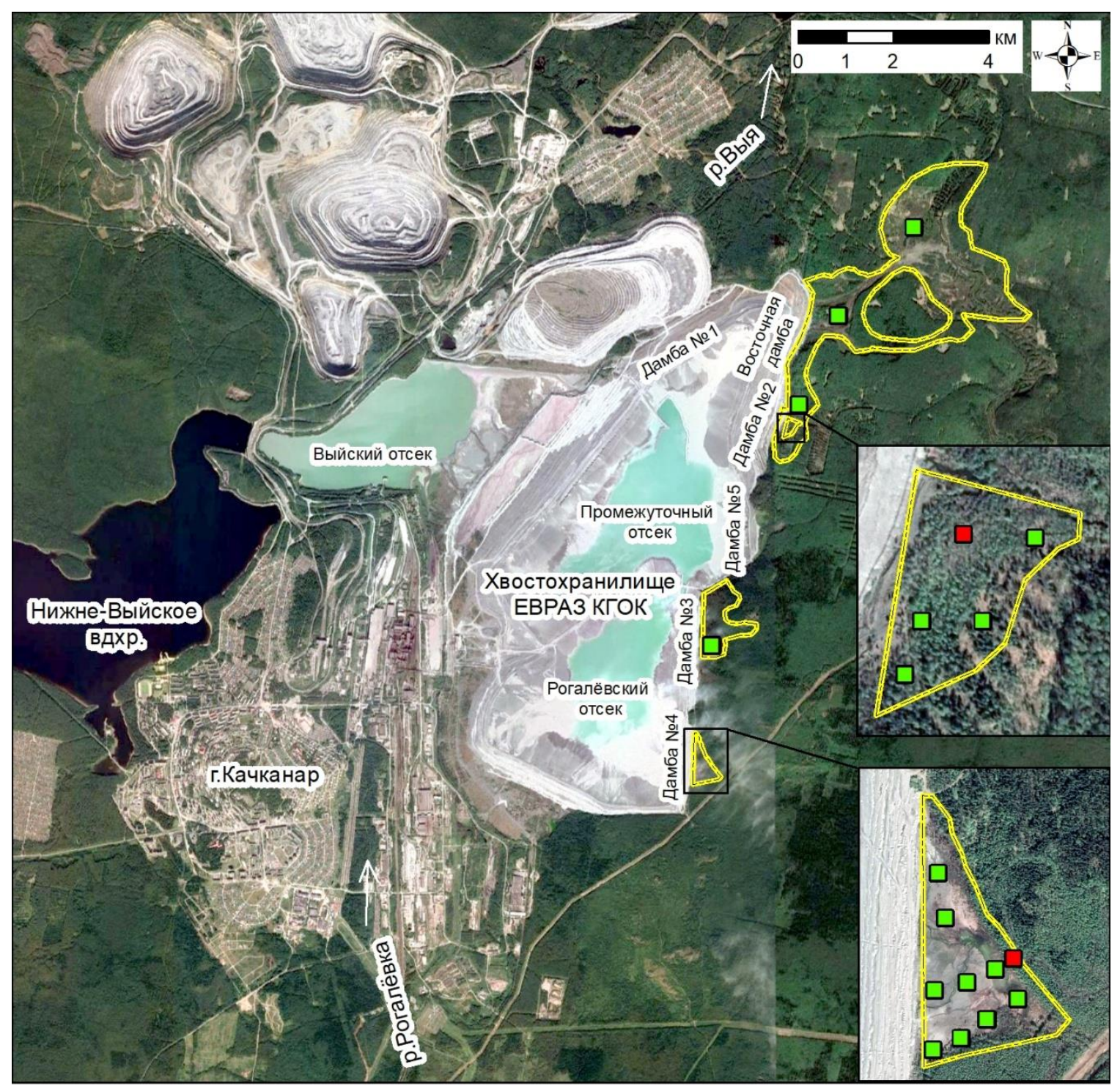

Условные обозначения

口 Пробная почвенная площадка

口 Фоновые участки почвенного обследования Участки развития техногенных

п_- поверхностных образований

Pис. 1. Схема хвостохранилищу $А О$ «ЕВРАЗ КГОК»

Fig. 1. Layout of the tailing dump of «EVRAZ KGOK»

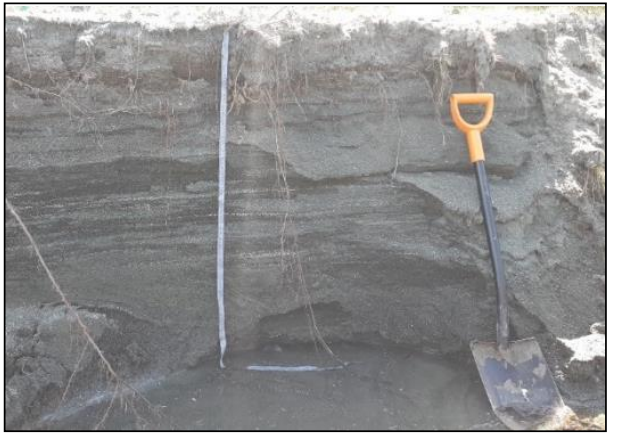

Pис. 2. Морфологический профиль техногенных поверхностных образований

Fig. 2. Morphological profile of technogenic surface formations
На техногенных грунтах участка в районе дамбы Рогалевского отсека отмечены процессы самозарастания с развитием молодого подроста сосны (рис. $3, a$ ), березы, рябины, ивы, травяной растительности (рис. 3, б). Эти процессы более активно идут у кромки леса на восточной и южной границах участка. Проективное покрытие лесных молодняков вблизи кромок леса достигает $10 \%$. Процесс восстановленияпостепенно захватывает пространство к центру участка.

На участках самозарастания в морфологическом строении техногенных грунтов выделяется слоистость. Верхний слой трансформируется под воздействием растительности, наблюдаются первичные признаки почвообразования, свидетельством которого является образование лесной подстилки и накопление 
органического вещества в верхнем слое. Горизонты не сформированы. Почвенные слои бесструктурные.

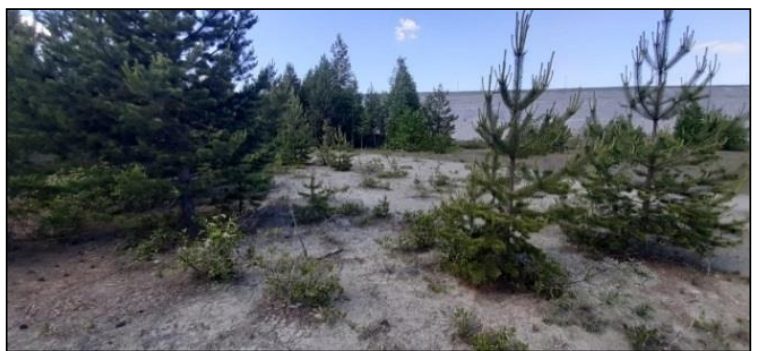

$a / a$
По состоянию растительного покрова возраст формирующихся почв составляет более 20 лет.

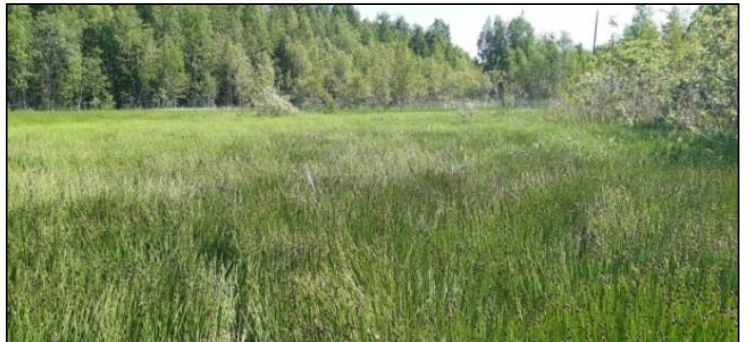

$\sigma / b$

Рис. 3. Процессы самозарастания на участке техногенных поверхностных образований в районе дамбы Рогалевского отсека

Fig. 3. Processes of self-overgrowing within technogenic surface formations in the area of the dam of the Rogalevsky section

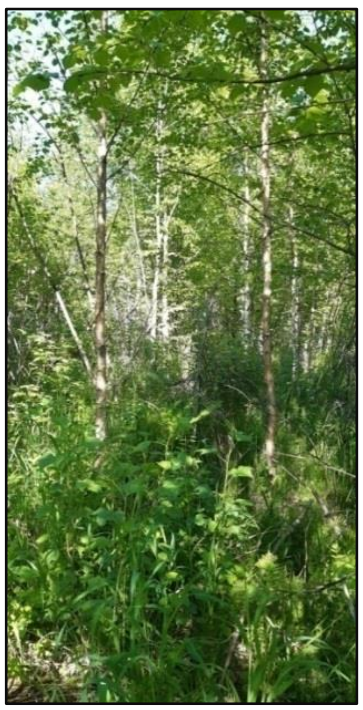

$a / a$

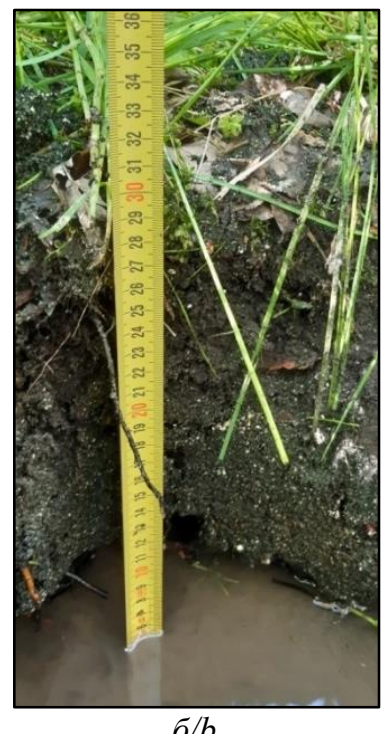

$\sigma / b$

Pис. 4. Вторичный смеманный лес (а) на техногенных поверхностных образованиях (б) в районе дамбы Промежуточного отсека

Fig. 4. Secondary mixed forest (a) on technogenic surface formations (b) in the area of the dam of the Intermediate section

На техногенных грунтахучастка в районе дамбы Промежуточного отсека произрастает вторичный смешанный лес возрастом 20-30 лет (рис. 4, a, б). Грунтыхарактеризуются наличием признаков начального почвообразования, свидетельством которого является образование лесной подстилки и накопление органического вещества в верхнем слое. Лесная подстилка имеет мощность около 3 см. Слои техногенных грунтов неоднородные по цвету, от темно-буросерого в верхнем слое мощностью около $20 \mathrm{~cm}$, до красно-коричневого в нижних слоях.

На исследуемых участках мощность слоя техногенных грунтов варьирует в зависимости от рельефа местности и достигает местами нескольких метров. Грунты вблизи кромки леса постепенно зарастают древесно-кустарниковой растительностью, а на расстоянии нескольких сотен метров от кромки леса местами практически полностью её лишены.
На техногенных грунтах в настоящее время сформировались смешанные лиственно-хвойные молодняки, средний возраст которых составляет 13-15 лет, состав 6С1Л3Б (доля участия в запасе древостоя: сосна $60 \%$, лиственница $10 \%$, береза $30 \%$ ), высота 2,5...3,0 м (рис. 5, a). Молодняки размещены по площади участка неравномерно. Состояние молодняков хорошее. Подавляющее большинство деревьев сосны и лиственницы находятся в жизнеспособном состоянии, не имеют признаков ослабления и повреждения. Средняя густота молодняков составляет 5000 шт./га, что свидетельствует об успешном лесовосстановлении главной породой. В составе подлеска указанных молодняков встречается ива прутовидная, ива пятитычинковая, шиповник коричный. Подлесок редкий, размещение его неравномерное. Coстояние подлеска хорошее (рис. 5, б).

Живой напочвенный покров техногенных грунтов встречается фрагментарно. Его проективное покрытие составляет в среднем $25 \%$, состояние хорошее. В составе живого напочвенного покрова встречаются вейник лесной, щучка дернистая, различные виды осок, клевер ползучий, клевер луговой, хвощ полевой, кладония оленья, кладония лесная, кладония альпийская, пельтигера собачья.

Проведенные обследования состояния растительности на техногенных грунтах позволяют сделать выводы об отсутствии видимых признаков их негативного воздействия на растительность. Лесовосстановительные процессы в целом идут активно сосной обыкновенной. На значительной части территории молодняки достигли стадии смыкания крон, что говорит об успешном формировании лесных насаждений и отсутствии необходимости проведения работ по рекультивации нарушенных земель.

Исследуемые техногенные грунты имеют песчаный механический состав, в отличие от природной почвы глинистого механического состава. Они характеризуются крайне низким содержанием органического вещества $(0,05 \ldots 0,16 \%)$ (табл. 2). Относительно повышенное содержание органического вещества $(0,13 \ldots 3,68 \%)$ характерно для техногенных грунтов на участке вторичного смешанного молодого леса с кустарниковой и травянистой растительностью, что связано с наличием лесной подстилки и начальных процессов гумусообразования на территории. Для сравне- 
ния органическое вещество в слое $0-10$ см зонального бурозема типичного составляет $7,55 \ldots 10,76 \%$, его со-

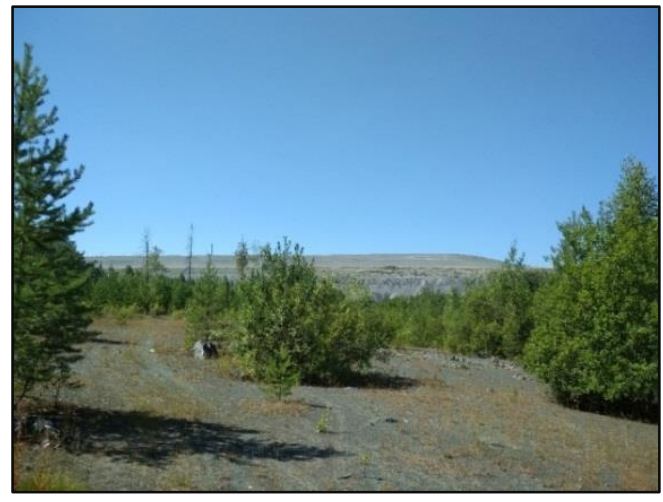

$a / a$ держание резко падает с глубиной - до 2,19...3,84 \% в слое $10-20 \mathrm{~cm}$.

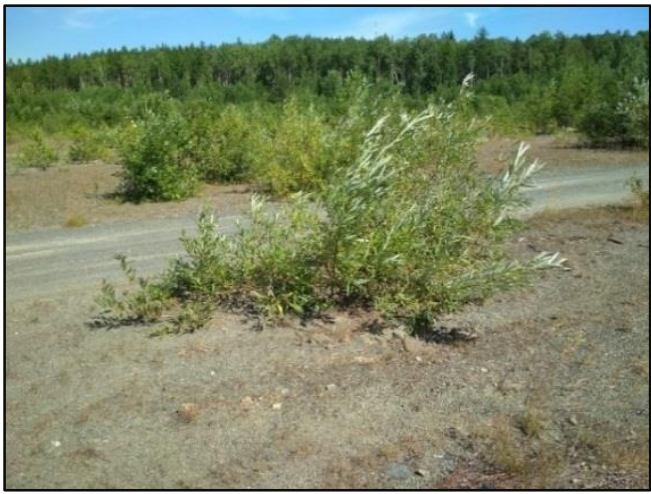

$\sigma / b$

Рис. 5. Лиственно-хвойные молодняки (а) и кустарниковые формы ивы (б), формирующиеся на техногенных грунтах

Fig. 5. Deciduous-coniferous young stands (a) and shrub forms of willow (b) forming on technogenic surface formations

Таблица 2. Количественные показатели состояния почв и техногенных грунтов природно-технической системы «Хвостохранилище КГОК»

Table 2. Quantitative indicators of condition of soils and technogenic surface formations of natural-technical system «EVRAZ KGOK tailing dump»

\begin{tabular}{|c|c|c|c|c|}
\hline \multirow[t]{2}{*}{ Показатель/Indicator } & \multicolumn{2}{|c|}{$\begin{array}{c}\text { Техногенные грунты, } \\
\text { глубина отбора, см } \\
\text { Technogenic surface formations, } \\
\text { sampling depth, cm }\left(\mathrm{n}^{*}=30\right)\end{array}$} & \multicolumn{2}{|c|}{$\begin{array}{l}\text { Бурозем типичный, } \\
\text { глубина отбора, см } \\
\text { Burozem typical, } \\
\text { sampling depth, cm }(\mathrm{n}=4)\end{array}$} \\
\hline & $0-10$ & $10-20$ & $0-10$ & $10-20$ \\
\hline $\begin{array}{l}\text { Содержание органического вещества, \% } \\
\text { Organic matter content, \% }\end{array}$ & $\frac{0,08 \ldots 3,68}{0,65}{ }^{* *}$ & $\frac{0,05 \ldots 0,99}{0,30}$ & $\frac{7,55 \ldots 10,76}{9,16}$ & $\frac{2,19 \ldots 3,84}{3,02}$ \\
\hline $\begin{array}{l}\text { pH водной вытяжки } \\
\text { pH of the water extract }\end{array}$ & $\frac{5,88 \ldots 7,58}{6,58}$ & $\frac{6,12 \ldots 7,50}{6,70}$ & $\frac{4,61 \ldots 6,27}{5,44}$ & $\frac{4,60 \ldots 6,28}{5,44}$ \\
\hline $\begin{array}{l}\text { pH солевой вытяжки } \\
\text { pH of the salt extract }\end{array}$ & $\frac{5,95 \ldots 7,75}{6,75}$ & $\frac{5,84 \ldots 7,64}{6,74}$ & $\frac{3,90 \ldots 5,98}{4,94}$ & $\frac{3,91 \ldots 5,64}{4,78}$ \\
\hline $\begin{array}{l}\mathrm{N} \text { общ., мг/кг } \\
\mathrm{N} \text { total, } \mathrm{mg} / \mathrm{kg}\end{array}$ & $\frac{63 \ldots 942}{206}$ & $\frac{42 \ldots 466}{164}$ & $\frac{1691 \ldots 2134}{1913}$ & $\frac{511 \ldots 725}{618}$ \\
\hline $\begin{array}{l}\mathrm{K}_{2} \mathrm{O}, \mathrm{M} \Gamma / \mathrm{K} \Gamma \\
\mathrm{K}_{2} \mathrm{O}, \mathrm{mg} / \mathrm{kg}\end{array}$ & $\frac{5,7 \ldots 61,4}{18,9}$ & $\frac{7,4 \ldots 55,1}{19,25}$ & $\frac{77,7 \ldots 147,9}{112,8}$ & $\frac{65,2 \ldots 79,1}{72,2}$ \\
\hline $\begin{array}{l}\mathrm{N}-\mathrm{NO}_{3}, \mathrm{M} \Gamma / \mathrm{K} \Gamma \\
\mathrm{N}-\mathrm{NO}_{3}, \mathrm{mg} / \mathrm{kg}\end{array}$ & $\frac{0,85 \ldots 2,65}{1,69}$ & $\frac{0,84 \ldots 2,25}{1,57}$ & $\frac{1,68 \ldots 3,35}{2,52}$ & $\frac{1,70 \ldots 3,15}{2,43}$ \\
\hline $\begin{array}{l}\text { Гидролитическая кислотность, ммоль/100 г } \\
\text { Hydrolytic acidity, mmol/100 g }\end{array}$ & $\frac{0,06 \ldots 0,88}{0,28}$ & $\frac{0,07 \ldots 1,93}{0,42}$ & $\frac{0,11 \ldots 2,84}{1,48}$ & $\frac{3,85 \ldots 5,48}{4,67}$ \\
\hline $\begin{array}{l}\text { Na обмен., ммоль } / 100 \text { г } \\
\text { Na exchange, mmol/100 g }\end{array}$ & $\frac{0,07 \ldots 0,22}{0,13}$ & $\frac{0,07 \ldots 0,50}{0,17}$ & $\frac{0,29 \ldots 0,36}{0,33}$ & $\frac{0,29 \ldots 0,43}{0,36}$ \\
\hline $\begin{array}{l}\text { Емкость поглощения (EКО), мг-экв/100 г } \\
\text { Absorption capacity, mg-eq/100 g }\end{array}$ & $\frac{8 \ldots 22}{14}$ & $\frac{10 \ldots 40}{14}$ & $\frac{36 \ldots 42}{39}$ & $\frac{30 \ldots 32}{31}$ \\
\hline $\begin{array}{l}\text { Доля Na от EКО, \% } \\
\text { Na share of absorption capacity, \% }\end{array}$ & $\frac{0,40 \ldots 2,61}{1,21}$ & $\frac{0,50 \ldots 5,00}{1,39}$ & $\frac{0,69 \ldots 1,00}{0,85}$ & $\frac{0,91 \ldots 1,43}{1,17}$ \\
\hline Сумма токсичных солей, \%/Toxic salts sum, \% & $<0,05$ & $<0,05$ & $<0,05$ & $<0,05$ \\
\hline $\begin{array}{l}\mathrm{Ni}, \mathrm{M \Gamma} / \mathrm{K \Gamma} \\
\mathrm{Ni}, \mathrm{mg} / \mathrm{kg}\end{array}$ & $\frac{57 \ldots 88}{69}$ & $\frac{54 \ldots 88}{67}$ & $\frac{50 \ldots 73}{62}$ & $\frac{37 \ldots 55}{46}$ \\
\hline $\begin{array}{l}\mathrm{Cu}, \mathrm{M \Gamma} / \mathrm{\kappa г} \\
\mathrm{Cui}, \mathrm{mg} / \mathrm{kg}\end{array}$ & $\frac{1 \ldots .53}{25}$ & $\frac{1 \ldots 76}{29}$ & $\frac{44 \ldots 67}{55}$ & $\frac{55 \ldots 60}{58}$ \\
\hline $\begin{array}{l}\mathrm{Zn}, \mathrm{M} \Gamma / \mathrm{\kappa} \Gamma \\
\mathrm{Zn}, \mathrm{mg} / \mathrm{kg}\end{array}$ & $\frac{66 \ldots 141}{96}$ & $\frac{72 \ldots 137}{101}$ & $\frac{154 \ldots 177}{166}$ & $\frac{90 \ldots 95}{93}$ \\
\hline $\begin{array}{l}\mathrm{As}, \mathrm{M \Gamma} / \mathrm{\kappa} \Gamma \\
\mathrm{As}, \mathrm{mg} / \mathrm{kg}\end{array}$ & $\frac{7 \ldots 13}{11}$ & $\frac{8 \ldots 13}{11}$ & $\frac{14 \ldots 17}{16}$ & $\frac{13,5 \ldots 13,8}{13,7}$ \\
\hline $\begin{array}{l}\mathrm{Cd}, \mathrm{M \Gamma} / \mathrm{K \Gamma} \\
\mathrm{Cd}, \mathrm{mg} / \mathrm{kg}\end{array}$ & $\frac{0,05 \ldots 0,41}{0,16}$ & $\frac{0,05 \ldots 0,73}{0,21}$ & $\frac{0,32 \ldots 0,35}{0,34}$ & $\frac{1,19 \ldots 1,40}{1,30}$ \\
\hline $\begin{array}{l}\mathrm{Hg}, \mathrm{M \Gamma} / \mathrm{K \Gamma} \\
\mathrm{Hg}, \mathrm{mg} / \mathrm{kg}\end{array}$ & $\frac{0,005 \ldots 0,019}{0,013}$ & $\frac{0,005 \ldots 0,027}{0,011}$ & $\frac{0,103 \ldots 0,113}{0,108}$ & $\frac{0,041 \ldots 0,045}{0,043}$ \\
\hline $\begin{array}{l}\mathrm{Pb}, \mathrm{M} \Gamma / \mathrm{K} \Gamma \\
\mathrm{Pb}, \mathrm{mg} / \mathrm{kg}\end{array}$ & $\frac{6 \ldots 23}{15}$ & $\frac{5 \ldots 45}{19}$ & $\frac{115 \ldots 119}{117}$ & $\frac{60 \ldots 73}{66}$ \\
\hline $\begin{array}{l}\text { Zc } \\
\text { Total pollution index }\end{array}$ & $\frac{1,09 \ldots 1,84}{1,33}$ & $\frac{1,42 \ldots 2,41}{1,86}$ & $\begin{array}{c}\text { фоH } \\
\text { background }\end{array}$ & $\begin{array}{c}\text { фон } \\
\text { background }\end{array}$ \\
\hline $\begin{array}{l}\text { Острая токсичность с использованием в качестве } \\
\text { тест-объекта Daphnia Magna Straus } \\
\text { Acute toxicity using Daphnia Magna Straus as test object }\end{array}$ & $\begin{array}{l}\text { Не оказь } \\
\text { токсичес } \\
\text { No acute }\end{array}$ & $\begin{array}{l}\text { острое } \\
\text { йствие } \\
\text { effects }\end{array}$ & $\begin{array}{l}\text { Не оказы } \\
\text { токсическ } \\
\text { No acute }\end{array}$ & $\begin{array}{l}\text { острое } \\
\text { ействие } \\
\text { effects }\end{array}$ \\
\hline
\end{tabular}

*Количество образиов почв. **В числителе - диапазон изменений, в знаменателе - среднее значение

*Number of soil samples. **The numerator is the range of variation, the denominator is the average value. 
Исследуемые грунты характеризуются близкой к нейтральной и нейтральной реакцией почвенной среды, о чем свидетельствует $\mathrm{pH}$ солевой вытяжки и значения гидролитической кислотности. Величина емкости катионного обмена техногенных грунтов преимущественно низкая и умеренно низкая (8-22 мгэкв/100 г), в некоторых слоях достигает 40 мгэкв/100 г, соответствуя умеренно высокому уровню. Доля обменного натрия от емкости поглощения в них составила от 0,40 до 5 \%, что указывает на незасоленный характер грунтов. Грунты характеризуются очень низким и низким содержанием обменного калия $\left(\mathrm{K}_{2} \mathrm{O}\right)$, а также очень низким содержанием азота общего и азота нитратного.

По солевой нагрузке состояние рассматриваемых грунтов удовлетворительное. Результаты оценки техногенной нагрузки по суммарному показателю загрязнения (коэффициент Zc) элементами 1-2 классов опасности свидетельствуют об их удовлетворительном экологическом состоянии: Zc не превышает 2,41 при допустимом уровне до 16 единиц. Суммарный показатель загрязнения определяется преимущественно повышенными содержаниями никеля, а также цинка в слое 10-20 см в техногенных грунтах по сравнению с почвами прилегающих территорий. Содержание остальных анализируемых элементов в них, как правило, ниже, чем в естественных почвах прилегающих территорий: меди в среднем в $2,1 \ldots 2,7$ раза; мышьяка - в $1,2 \ldots 1,5$; кадмия - в $2,1 \ldots 4,8$; ртути - в $2,9 \ldots 8,6$; свинца - в 2,8...7,8 раза.

По результатам анализов на острую токсичность с использованием в качестве тест-объекта Daphnia Magna Straus техногенные грунты характеризуются отсутствием острого токсического действия на исследуемые тест-системы.

В соответствии с методикой оценки, предложенной В.А. Андрохановым [40], почвенно-экологическое состояние рассматриваемой природно-технической системы в целом соответствует категории неудовлетворительного: морфологическое строение ТПО соответствует эмбриоземам органо-аккумулятивным, процесс восстановления растительности по площади протекает неравномерно, активизируясь на участках вблизи существующего леса. Только почвенноэкологическое состояние участка в районе дамбы Промежуточного отсека, покрытого вторичным смешанным лесом, произрастающим на ТПО с более выраженными признаками начального почвообразования, можно охарактеризовать как удовлетворительное.

Тем не менее проведенные исследования позволяют сделать вывод о достаточно благоприятных условиях восстановления экосистем и сохранения

\section{СПИСОК ЛИТЕРАТУРЫ}

1. Геохимическая трансформация ландшафтов железногорского промышленного ареала (Курская область)/ О.В. Кайданова, И.В. Замотаев, С.Б. Суслова, Г.С. Шилькрот // Известия Российской академии наук. Серия географическая.- 2018. № 3. - С. 91-104.

2. Исаев С.В. Концепция природно-технических систем и ее использование при изучении антропогенной трансформации ими потенциала самовосстановления. Техногенные грунты (техногенные поверхностные образования) не являются токсичными и не оказывают негативного воздействия на растительность. Восстановление растительности в целом идет активно по зональному типу с преобладанием в составе растительного покрова основных пород.

\section{Заключение}

Таким образом, техногенные грунты, представленные хвостами мокрой магнитной сепарации песчаной фракции, диагностированы как техногенные поверхностные образования группы артифабрикаты, подгруппы артииндустраты. По сравнению с фоновыми почвами они характеризуются меньшим содержанием органического вещества, общего азота, менее кислой реакцией почвенного раствора, по содержанию водорастворимых ионов являются незасоленными, характеризуются допустимым уровнем загрязнения элементами 1-2 классов опасности и отсутствием острого токсического действия на исследуемые тестсистемы.

Активное протекание лесовосстановительных процессов на техногенных грунтах и удовлетворительное состояние растительности без признаков угнетения позволяет утверждать об отсутствии их негативного воздействия на растительность. Вслед за восстановлением растительности в техногенных грунтах появляются признаки начального почвообразования, свидетельством которого является образование лесной подстилки, накопление органического вещества в верхних слоях и начальная дифференциация почвенных горизонтов.

Почвенно-экологическое состояние природнотехнической системы хвостохранилища Качканарского горно-обогатительного комбината можно признать удовлетворительным, не требующим в настоящее время проведения специальных природоохранных мероприятий по восстановлению почвенного и растительного слоя на участках выноса отходов за пределы хвостохранилища в результате аварийного прорыва дамбы и фильтрационной разгрузки сточных вод в основании дамб хвостохранилища.

Экосистемы сохраняют потенциал самовосстановления, за счет чего в перспективе после окончания эксплуатации хвостохранилища можно ожидать благоприятное течение процессов восстановления почвенно-растительного покрова и экологических условий окружающей среды в целом.

Исследования выполнены при финансовой поддержке Пермского научно-образовательного чентра «Рациональное недропользование», 2021 г.

природной среды // Географический вестник. - 2016. № 3 (38). - C. 105-113. DOI:10.17072/2079-7877-2016-3-105-113.

3. Бондарик Г.К. Экологическая проблема и природнотехнические системы. - М.: Икар, 2004. - 152 с.

4. Ярг Л.А., Житинская О.М. Информационные основы обеспечения оптимальной эксплуатации природно-технических систем «рудные месторождения» // Известия высших учебных заведений. Геология и разведка. - 2017. - № 5. - С. 78-81. 
5. Андроханов В.А. Почвенно-экологическое состояние техногенных ландшафтов: динамика и оценка: автореф. дис. ... д-ра биол. наук. - Новосибирск, 2005. - 35 с.

6. Шабанов М.В., Маричев М.С. Оценка трансформации природно-территориальных комплексов при горнопромышленном техногенезе // Известия Томского политехнического университета. Инжиниринг георесурсов. - 2020. - Т. 331. - № 3. C. $90-99$.

7. Karaca O., Cameselle C., Reddy K.R. Mine tailing disposal sites: contamination problems, remedial options and phytocaps for sustainable remediation // Reviewsin Environmental Science and Bio/Technology. - 2018. - V. 17 (1). - P. 205-228. DOI: 10.1007/s11157-017-9453-y

8. Analysis of air and soil quality regarding the cross-border impact risk of the mining tailings ponds in Moldova Nouă Area S. Raischi, E. Pană, E. Holban, S. Zamfir, M. Raischi, G. Deák // International Journal of Environmental Science and Development. - June 2019. - V.10. - № 6. - P. 162-170. DOI 10.18178/ijesd.2019.10.6.1166.

9. ИсследованиеэкологическоговоздействияНовотроицкогохвостохранилища на растительный покров и живые организмы М.В. Рыльникова, Д.Н. Радченко, М.В. Цупкина, В.А. Сафонов // Известия Тульского государственного университета. Науки о Земле. - 2020. - № 1. - С. 108-120.

10. Стровский В.Е., Кубарев М.С. Обеспечение экологической безопасности в условиях моногородов горнопромышленного комплекса // Известия высших учебных заведений. Горный журнал. - 2018. - № 6. - С. 99-108.

11. García-Giménez R., Jiménez-Ballesta R. Mine tailings influencing soil contamination by potentially toxic elements // Environmental Earth Sciences. - 2017. - V. 76. - Article number 51 DOI: $10.1007 / \mathrm{s} 12665-016-6376-9$

12. Khayrulina E., Maksimovich N. Influence of drainage with high contents of water-soluble salts on the environment in the Verhnekamskoe potash deposit, Russia // Mine Water and the Environment. - 2018. - V. 37. - P. 595-603.

13. Transformation and contamination of soils in iron ore mining areas (a review) / I.V. Zamotaev, I.V. Ivanov, P.V. Mikheev, V.P. Belobrov // Eurasian Soil Science. - 2017. - 50. - P. 359-372 DOI: 10.1134/S1064229317030127

14. Брагина П.С., Герасимова М.И. Почвообразовательные процессы на отвалах горнодобывающих предприятий (на примере юга Кемеровской области) // География и природные ресурсы. - 2014. - № 1. - С. 45-51.

15. Полевой определитель почв России / под ред. К.Т. Остриковой. - М.: Почв. ин-т им. В.В. Докучаева, 2008. - 182c.

16. Введение почв и почвоподобных образований городских территорий в классификацию почв России / Т.В. Прокофьева, М.И. Герасимова, О.С. Безуглова, К.А. Бахматова, А.А. Гольева, С.Н. Горбов, Е.А. Жарикова, Н.Н. Матинян, Е.Н. Наквасина, Н.Е. Сивцева // Почвоведение. - 2014. - № 10. - С. 1-10.

17. Андроханов В.А., Куляпина Е.Д., Курачев В.М. Почвы техногенных ландшафтов: генезис и эволюция. - Новосибирск: Изд-во СО РАН, 2004. - 151 с

18. Андроханов В.А., Курачев В.М. Почвенно-экологическое состояние техногенных ландшафтов: динамика и оценка. - Новосибирск: Изд-во СО РАН, 2010. - 224 с.

19. Характеристика почвенно-экологического состояния природно-техногенных комплексов г. Новокузнецк / О.Г. Берлякова, В.Г. Двуреченский, А.А. Топоровская, Н.Б. Ермак // Антропогенная трансформация природной среды. - 2011. - № 1. C. $153-159$.

20. Почвенно-экологическое состояние урбанизированных территорий Западной Сибири (на примере г. Новокузнецка) В.Г. Двуреченский, Д.А. Соколов, А.А. Топоровская, О.Г. Берлякова // Почвоведение и агрохимия. - 2011. - № 2. - С. 5-13.

21. Двуреченский В.Г., Андроханов В.А. Почвенноэкологическое состояние техногенных ландшафтов Новокузнецкого промышленного комплекса // Живые и биокосные системы. - 2017. - № 20. URL: http://www.jbks.ru/archive/issue20/article-3 (дата обращения: 12.02.2021).

22. Брагина П.С., Герасимова М.И. Техногенные поверхностные образования на отвалах и хвостохранилищах в Кемеровской области: опыт классификации // Бюллетень почвенного института им. В.В. Докучаева. - 2017. - № 89. - С. 90-103.
23. Процессы первичного почвообразования на нефелинсодержащих отходах (на примере хвостохранилищ ОАО «АПАТИТ») / Г.А. Евдокимова, В.Н. Переверзев, И.В. Зенкова, М.В. Корнейкова, В.В. Редькина // Вестник КНЦ. - 2011. № 1. - C. 34-48.

24. Первичные процессы почвообразования в условиях естественного зарастания техногенно-нарушенных ландшафтов / Ф.Е. Козыбаева, Г.Б. Бейсеева, С. Утугельбаев, А.А. Курманбаев, К.А. Даутбаева // Почвоведение и агрохимия. - 2010. № 3. - C. 13-25.

25. Кондакова Л.В., Дабах Е.В., Кислицына А.П. Формирование биоценоза на техногенных отходах // Теоретическая и прикладная экология. - 2020. - № 4. - С. 129-135.

26. Чадаева В.А., Цепкова Н.Л., Жашуев А.Ж. Многолетняя динамика восстановления растительности техногенных ландшафтов Былымской аридной котловины (Центральный Кавказ) // Аридные экосистемы. - 2020. - Т. 26. - № 4 (85).- С. 127-135.

27. Reduction of seepage outflow from potash tailings piles by improvement of greening: results of a hydrological simulation / C. Hildmann, L. Rösel, B. Zimmermann, D. Knoche, W.-D. Hartung, F.-C. Benthaus // Mining meets water - conflicts and solutions: Proc. - Freiberg: TU Bergakademie Freiberg, 2016. - P. 772-779.

28. Morphogenetic diagnostics of soil formation on tailing dumps of coal quarries in Siberia / D.A. Sokolov, V.A. Androkhanov, S.P. Kulizhskii, E.A. Domozhakova, S.V. Loiko // Eurasian Soil Science. - 2015. - V. 48 (1). - P. 95-105. DOI: $10.1134 / \mathrm{S} 1064229315010159$

29. Техногенные поверхностные образования в границах влияния горно-промышленной системы Дальнегорского района Приморского края как объект рекультивации / Л.Т. Крупская, Д.А. Голубев, М.Ю. Филатова, В.А. Андроханов, И.П. Беланов // Стратегии развития современной науки: сборник научных статей. - М.: Изд-во «Перо», 2019. - С. 183-192.

30. Опыты биологической рекультивации на хвостохранилищах Западной Якутии / С.И. Миронова, Л.Д. Гаврильева, З.А. Кудинова, А.А. Петрова // Успехи современного естествознания. -2015 . - № 12. - С. 72-76.

31. Fang Chen, Qiang Yao, Jingyi Tian. Review of ecological restoration technology for mine tailings in China // Engineering Review. - 2016. - V. 36. - Iss. 2. - P. 115-121.

32. Soil-covered strategy for ecological restoration alters the bacterial community structure and predictive energy metabolic functions in mine tailings profiles / Yang Li, Qingye Sun, Jing Zhan, Yang Yang, Dan Wang // Applied Microbiology and Biotechnology. 2017. - V. 101 (6). - P. 2549-2561.DOI: 10.1007/s00253-0167969-7

33. Plant species diversity for vegetation restoration in manganese tailing wasteland / Jun Wang, Xinghua Luo, Yifan Zhang, Yanhong Huang, Manikandan Rajendran, Shengguo Xue // Environmental Science Pollution Research. - 2018. - V. 25 (1). P. 24101-24110.DOI: 10.1007/s11356-018-2275-9

34. Основные направления преобразования техноземов в культурные ландшафты / А.И. Стифеев, О.В. Никитина, О.В. Нагорная, Е.Н. Панова, Е.С. Николаева // Вестник Курской государственной сельскохозяйственной академии. 2019. - № 3. - C. 28-34.

35. Occurrence of pharmaceutical and personal care products (PPCPs) in marine sediments in the Todos os Santos Bay and the north coast of Salvador, Bahia, Brazil / M. Beretta, V. Britto, T.M. Tavares, S.M. da Silva, A.L. Pletsch // Journal of Soils and Sediments. - 2014. - V. 14 (7). - P. 1278-1286.

36. Removal of heavy metals from lead-zinc mine tailings by improved electrokinetic technique / S. Wang, Y. Liu, X. Li, L. Peng, W. Xia // Environment Protection of Chemical Industry. 2008. - V. 4. - P. 331-335.

37. Krasilnikova S., Blinov S. Global experience in the Use of soda waste // 20th International Multidisciplinary Scientific GeoConference SGEM 2020. Conference Proceedings. - Bulgaria, Sofia, 2020. - P. 19-26. DOI: 10.5593/sgem2020V/4.2/s05.03

38. Effectsof organic amendments and biochar on ecological remediation of ionic rare earth mine tailings / Y. Chen, W. Liu, K. Ding, Y. Tang, R. Qiu // Acta Scientiae Circumstantiae. - 2018. V. 38 (12). - P. 4769-4778. DOI: 10.13671/j.hjkxxb.2018.0295 
39. Chicken Manure Biochar as Liming and Nutrient Source for Acid Appalachian Soil / A. Hass, J.M. Gonzalez, I.M. Lima, H.W. Godwin, J.J. Halvorson, D.G. Boyer // Journal of Environmental Quality. - 2012. - V. 41 (4). - P. 1096-1106. DOI: $10.2134 /$ jeq2011.0124

40. Андроханов В.А., Курачев В.М. Принципы оценки почвенноэкологического состояния техногенных ландшафтов // Сибирский экологический журнал. - 2009. - Т. 16. - № 2. - С. 165-169.

41. Reducing the negative technogenic impact of the mining enterprise on the environment through management of the water balance / E. Menshikova, V. Fetisov, T. Karavaeva, S. Blinov, P. Belkin, S. Vaganov // Minerals. - 2020. - V. 10. - 1145. DOI: 10.3390/min10121145

42. Menshikova E., Blinov S., Vaganov S. Recovery of valuable elements from tailings of the Kachkanar Ore Mining and
Processing Plant //Mine Water: Technological and Environmental Challenges. Proceedings of International Mine Water Association Conference 2019. - Russia, Perm: Perm State University, Perm Federal Research Center of the Ural Branch of RAS, 2019. P. 527-530

43. Гафуров Ф.Г. Почвы Свердловской области. - Екатеринбург: Из-во Урал. ун-та, 2008. - 396 с.

44. Фирсова В.П.Почвы таежной зоны Урала и Зауралья. - М.: Наука, 1976. - $176 \mathrm{c}$.

45. Колесников Б.П. Лесохозяйственное районирование и лесной фонд. Леса Свердловской области // Леса СССР.- М.: Наука, 1969. - T.4. $-250 \mathrm{c}$

Поступила 18.08.2021 г.

\section{Информация об авторах}

Mеньшикова E.A., кандидат геолого-минералогических наук, ведущий научный сотрудник лаборатории экологической геологии Естественнонаучного института Пермского государственного национального исследов ательского университета.

Караваева Т.И., кандидат геолого-минералогических наук, старший научный сотрудник лаборатории экологической геологии Естественнонаучного института Пермского государственного национального исследовательского университета.

Хайрулина E.A., кандидат географических наук, директор Естественнонаучного института Пермского государственного национального исследовательского университета.

Митракова Н.B., кандидат биологических наук, старший научный сотрудник лаборатории биогеохимии техногенных ландшафтов Естественнонаучного института Пермского государственного национального исследовательского университета. 
UDC 502.5

\title{
SPECIFIC FEATURES OF SOIL AND ECOLOGICAL STATE OF NATURAL TECHNICAL SYSTEM «EVRAZ KGOK TAILING DUMP»
}

\author{
Elena A. Menshikova ${ }^{1}$, \\ menshikova_e@list.ru
}

Tatyana I. Karavaeva', jewel_@list.ru

Elena A. Khayrulina 1 , elenakhay@gmail.com

\author{
Natalya V. Mitrakova', \\ mitrakovanatalya@mail.ru \\ 1 Perm State National Research University, \\ 4, Genkel street, Perm, 614990, Russia.
}

The relevance. Soil-ecological potential of technogenic landscape among other components is determined by properties of lithogenic resource, which for mining areas are, primarily, heavy tonnage wastes - overburden rocks and mineral processing wastes.

The purpose of this work is to assess the soil-ecological state of the natural-technical system of the tailings dump of the Kachkanarsky Ore Mining and Processing Plant and to identify prospects of ecosystems development and potential for their self-restoration.

The research objectives included identification of soil formation features and determination of basic agrochemical and environmental characteristics of technogenic surface formations, assessment of their phytotoxicity, assessment of the vegetation cover condition, and identification of the need for reclamation.

The object of the study is technogenic soils, which are part of the lithogenic basis of the natural and technical system of the tailings dump of the Kachkanarsky Ore Mining and Processing Plant.

Methods. The study of technogenic surface formations was carried out in the areas of their removal outside the tailings dump. The field studies included general acquaintance with the area, field study of soils and technogenic surface formations, soil sampling, and study of vegetation cover of the area. Laboratory investigations were carried out in specialized laboratories using unified methods. The content of microelements was determined by ICP-MS method.

Results. According to obtained results, natural and technogenic deposits represented by tailings of wet magnetic separation of sand fraction are identified as technogenic surface formations of artifact group, artiindustrates subgroup. Compared with the background soils, they are characterized by lower content of organic matter, total nitrogen, and less acidic reaction of the soil solution. They are non-saline in the content of water-soluble ions and are characterized by the admissible level of pollution by elements of hazard classes 1-2 and the absence of acute toxic effect on the studied biological test systems. Active reforestation processes on technogenic surface formations and satisfactory state of vegetation demonstrate the absence of negative effect of the mentioned deposits on the vegetation. Following revegetation of technogenic surface formations, signs of initial soil formation appear. These processes are identified by formation of forest floor, accumulation of organic matter in the upper layers, and initial differentiation of soil horizons. The soil-ecological state of the studied natural-technical system can be recognized as satisfactory. Currently, no special environmental protection measures are required to restore the soil and vegetation layer at the waste disposal sites outside the tailings management facility.

\section{Key words:}

Tailing dump, technogenic grounds, soil, technogenic surface formations, vegetation cover, condition assessment, soil and ecological state, natural and technical system, technogenic landscapes.

The research was supported by the Perm Research and Education Centre for Rational Use of Subsoil, 2021.

\section{REFERENCES}

1. Kaidanova O.V., Zamotaev I.V., Suslova S.B., Shilkrot G.S Geochemical transformation of landscapes of the Zheleznogorsk industrial area (Kurskregion). Bulletin of the Russian Academy of Sciences, Geographical series, 2018, no. 3, pp. 91-104. In Rus.

2. Isaev S.V. The concept of natural and technical systems and its use in the study of anthropogenic transformation of the natural environment. Geographical bulletin, 2016, no. 3 (38), pp. 105-113 In Rus. DOI: 10.17072 / 2079-7877-2016-3-105-113.

3. Bondarik G.K. Informatsionnye osnovy obespecheniya optimalnoy ekspluatatsii prirodno-tekhnicheskikh sistem «rudnye mestorozhdeniya» [Ecological problem and natural-technical systems]. Moscow, Ikar Publ., 2006. 152 p.

4. Yarg L.A., Zhitinskaya O.M. Information bases for ensuring the optimal operation of natural and technical systems «ore deposits». Proceedings of higher educational institutions, Geology and exploration, 2017, no. 5, pp. 78-81. In Rus.
5. Androkhanov V.A. Pochvenno-ekologicheskoe sostoyanie tekhnogennykh landshaftov: dinamika i otsenka. Avtoreferat Dis. Dokt. nauk [Soil-ecological state of technogenic landscapes: dynamics and assessment. Dr. Diss. Abstract]. Novosibirsk, 2005. $35 \mathrm{p}$.

6. Shabanov M.V., Marichev M.S. Assessment of the transformation of natural-territorial complexes during mining technogenesis. Bulletin of the Tomsk Polytechnic University. Engineering of Georesources, 2020, vol. 331, no. 3, pp. 90-99. In Rus.

7. Karaca O., Cameselle C., Reddy K.R. Mine tailing disposal sites: contamination problems, remedial options and phytocaps for sustainable remediation. Reviews in Environmental Science and Bio/Technology, 2018, vol. 17 (1), pp. 205-228. DOI: 10.1007/s11157-017-9453-y

8. Raischi S., Pană E., HolbanE., Zamfir S.,, Raischi M., Deák G. Analysis of air and soil quality regarding the cross-border impact risk of the mining tailings ponds in Moldova Nouă Area. 
International Journal of Environmental Science and Development, June 2019, vol. 10, no. 6, pp. 162-170. DOI: 10.18178/ijesd. 2019.10.6.1166.

9. Rylnikova M.V., Radchenko D.N., Tsupkina M.V., Safonov V.A. Study of the environmental impact of the Novotroitsk tailing dump on vegetation and living organisms. Bulletin of the Tula State University, Earth Sciences, 2020, no. 1, pp. 108-120. In Rus.

10. Strovsky V.E., Kubarev M.S. Ensuring environmental safety in the conditions of single-industry towns of the mining complex. Proceedings of higher educational institutions, Mining magazine, 2018, no. 6, pp. 99-108. In Rus.

11. García-Giménez R., Jiménez-Ballesta R. Mine tailings influencing soil contamination by potentially toxic elements. Environmental Earth Sciences, 2017, vol. 76, 51. DOI: 10.1007/s12665-0166376-9.

12. Khayrulina E., Maksimovich N. Influence of drainage with high contents of water-soluble salts on the environment in the Verhnekamskoe potash deposit, Russia. Mine Water and the Environment, 2018, 37, pp. 595-603.

13. Zamotaev I.V., Ivanov I.V., Mikheev P.V., Belobrov V.P. Transformation and contamination of soils in iron ore mining areas (a review). Eurasian Soil Science, 2017, vol. 50, pp. 359-372. DOI: $10.1134 /$ S1064229317030127

14. Bragina P.S., Gerasimova M.I. Soil-forming processes in the dumps of mining enterprises (for example, the south of the Kemerovo region). Geography and natural resources, 2014, no. 1 , pp. 45-51. In Rus.

15. Polevoy opredelitel pochv Rossii [Field guide to soils of Russia] Ed. by K.T. Ostrikova. Moscow, V.V. Dokuchaev Publ., 2008. $182 \mathrm{p}$.

16. Prokofieva T.V., Gerasimova M.I., Bezuglova O.S., Bakhmatova K.A., Golieva A.A., Gorbov S.N., Zharikova E.A., Matinyan N.N., Nakvasina E.N., Sivtseva N.E. Vvedenie pochv i pochvopodobnykh obrazovaniy gorodskikh territoriy v klassifikatsiyu pochv Rossii [Introduction of soils and soil-like formations of urban areas into the classification of soils in Russia]. Soil science, 2014, no. 10, pp. 1-10.

17. Androkhanov V.A., Kulyapina E.D., Kurachev V.M. Pochvy tekhnogennykh landshaftov: genezis $i$ evolyutsiya [Soils of technogenic landscapes: genesis and evolution]. Novosibirsk, SB RAS Publ. house, 2004. $151 \mathrm{p}$

18. Androkhanov V.A., Kurachev V.M. Pochvy tekhnogennykh landshaftov: genezis i evolyutsiya [Principles of assessing the soilecological state of technogenic landscapes]. Siberian ecological journal, 2009, vol. 16, no. 2, pp. 165-169.

19. Berlyakova O.G., Dvurechensky V.G., Toporovskaya A.A., Ermak N.B. Characteristics of the soil and ecological state of natural and technogenic complexes in Novokuznetsk. Anthropogenic transformation of the Natural Environment, 2011, no. 1 , pp. 153-159. In Rus.

20. Dvurechensky V.G., Sokolov D.A., Toporovskaya A.A., Berlyakova O.G. Soil-ecological state of urbanized territories of Western Siberia (on the example of Novokuznetsk). Soil science and agrochemistry, 2011, no. 2, pp. 5-13. In Rus.

21. Dvurechensky V.G., Androkhanov V.A. Soil and ecological state of technogenic landscapes of the Novokuznetsk industrial complex. Living and bioinert systems, 2017, no. 20. In Rus. Available at: http://www.jbks.ru/archive/issue-20/article-3 (accessed 12 February 2021).

22. Bragina P.S., Gerasimova M.I. Technogenic surface formations on dumps and tailings in the Kemerovo region: classification experience. Bulletin of the Soil Institute V.V. Dokuchaeva, 2017, no. 89 , pp. 90-103. In Rus.

23. Evdokimova G.A., Pereverzev V.N., Zenkova I.V. Korneikova M.V., Redkina V.V. Protsessy pervichnogo pochvoobrazovaniya na nefelinsoderzhashchikh othodakh (na primere khvostokhranilishch OAO "APATIT» [Processes of primary soil formation on nepheline-containing wastes (on the example of tailing dumps of APATIT)]. Bulletin of the KSC, 2011, no. 1, pp. 34-48.

24. Kozybaeva F.E., Beiseeva G.B., Utugelbaev S., Kurmanbaev A.A., Dautbaeva K.A. Primary processes of soil formation in conditions of natural overgrowing of technologically disturbed landscapes. Soil science and agrochemistry, 2010, no. 3, pp. 13-25. In Rus.
25. Kondakova L.V., Dabakh E.V., Kislitsyna A.P. Formation of biocenosis on technogenic waste. Theoretical and Applied Ecology, 2020, no. 4, pp. 129-135. In Rus.

26. Chadayeva V.A., Tsepkova N.L., Zhashuev A.Zh. Mnogoletnyaya dinamika vosstanovleniya rastitelnosti tekhnogennykh landshaftov Bylymskoy aridnoy kotloviny (Tsentralny Kavkaz) [Long-term dynamics of restoration of vegetation of technogenic landscapes of the Bylym arid basin (Central Caucasus)]. Arid ecosystems, 2020, no. 4 (85), vol. 26, pp. 127-135.

27. Hildmann C., Rösel L., Zimmermann B., Knoche D., Hartung W.-D., Benthaus F.-C. Reduction of seepage outflow from potash tailings piles by improvement of greening: Results of a hydrological simulation. Mining Meets Water - Conflicts and Solutions: Proceedings. Freiberg, TU Bergakademie Freiberg, 2016. pp. 772-779.

28. Sokolov D.A., Androkhanov V.A., Kulizhskii S.P., Domozhakova E.A., Loiko S.V. Morphogenetic diagnostics of soil formation on tailing dumps of coal quarries in Siberia. Eurasian Soil Science, 2015, vol. 48 (1), pp. 95-105. DOI: $10.1134 / \mathrm{S} 1064229315010159$.

29. Krupskaya L.T., Golubev D.A., Filatova M.Yu., Androkhanov V.A., Belanov I.P. Tekhnogennye poverkhnostnye obrazovaniya v granitsakh vliyaniya gorno-promyshlennoy sistemy Dalnegorskogo rayona Primorskogo kraya kak obekt rekultivatsii [Technogenic surface formations within the influence of the mining and industrial system of the Dalnegorsk district of Primorsky Krai as an object reclamation]. Strategii razvitiya sovremennoy nauki: sbornik nauchnykh statey [Strategies for the development of modern science: a collection of scientific articles]. Moscow, Pero Publ. house, 2019. pp. 183-192.

30. Mironova S.I., Gavrileva L.D., Kudinova Z.A., Petrova A.A. Opyty biologicheskoy rekultivatsii na khvostokhranilishchakh Zapadnoy Yakutii [Experiments in biological reclamation at tailing dumps in Western Yakutia]. Successes of modern natural science, 2015, no. 12, pp. 72-76. In Rus.

31. Fang Chen, Qiang Yao, Jingyi Tian. Review of ecological restoration technology for mine tailings in China. Engineering Review, 2016, vol. 36, Iss. 2, pp. 115-121.

32. Yang Li, Qingye Sun, Jing Zhan, Yang Yang, Dan Wang. Soilcovered strategy for ecological restoration alters the bacterial community structure and predictive energy metabolic functions in mine tailings profiles. Applied Microbiology and Biotechnology, 2017, vol. 101 (6), pp. 2549-2561. DOI: 10.1007/s00253-0167969-7

33. Jun Wang, Xinghua Luo, Yifan Zhang, Yanhong Huang, Manikandan Rajendran, Shengguo Xue. Plant species diversity for vegetation restoration in manganese tailing wasteland. Environmental Science Pollution Research, 2018, vol. 25(1), pp. 24101-24110. DOI: 10.1007/s11356-018-2275-9

34. Stifeev A.I., Nikitina O.V., Nagornaya O.V., Panova E.N., Nikolaeva E.S. The main directions of transformation of technozems into cultural landscapes. Bulletin of the Kursk State Agricultural Academy, 2019, no. 3, pp. 28-34. In Rus.

35. Beretta M., Britto V., Tavares T.M., da Silva S.M., Pletsch A.L. Occurrence of pharmaceutical and personal care products (PPCPs) in marine sediments in the Todos os Santos Bay and the north coast of Salvador, Bahia, Brazil. Journal of Soils and Sediments, 2014, vol. 14 (7), pp. 1278-1286.

36. Wang S., Liu Y., Li X., Peng L., and Xia W. Removal of heavy metals from lead-zinc mine tailings by improved electrokinetic technique. Environment Protection of Chemical Industry, 2008, vol. 4, pp. 331-335.

37. Krasilnikova S., Blinov S. Global experience in the Use of soda waste. $20^{\text {th }}$ International Multidisciplinary Scientific GeoConference - SGEM 2020. Conference Proceedings. Bulgaria, Sofia, 2020. pp. 19-26. DOI: 10.5593/sgem2020V/4.2/s05.03

38. Chen Y., Liu W., Ding K., Tang Y., Qiu R. Effectsof organic amendments and biochar on ecological remediation of ionic rare earth mine tailings. Acta Scientiae Circumstantiae, 2018, vol. 38 (12), pp. 4769-4778. DOI: 10.13671/j.hjkxxb.2018.0295

39. Hass A., Gonzalez J.M., Lima I.M., Godwin H.W., Halvorson J.J., Boyer D.G. Chicken Manure Biochar as Liming and Nutrient Source for Acid Appalachian Soil. Journal of Environmental Quality, 2012, vol. 41(4), pp. 1096-1106. DOI: 10.2134/jeq2011.0124 
40. Androkhanov V.A., Kurachev V.M. Principles of assessing the soil-ecological state of technogenic landscapes. Siberian ecological journal, 2009, vol. 16, no. 2, pp. 165-169. In Rus.

41. Menshikova E., Fetisov V., Karavaeva T., Blinov S., Belkin P., Vaganov S. Reducing the Negative Technogenic Impact of the Mining Enterprise on the Environment through Management of the Water Balance. Minerals, 2020, vol. 10, 1145. DOI 10.3390/min10121145.

42. Menshikova E., Blinov S., Vaganov S. Recovery of valuable elements from tailings of the Kachkanar Ore Mining and Processing Plant. Mine Water: Technological and Environmental Challenges. Proceedings of International Mine Water Association Conference 2019. Russia, Perm, Perm State University, Perm
Federal Research Center of the Ural Branch of RAS, 2019. pp. 527-530.

43. Gafurov F.G. Pochvy Sverdlovskoy oblasti [Soils of the Sverdlovsk region]. Yekaterinburg, Ural University Publ. House, 2008. $396 \mathrm{p}$.

44. Firsova V.P. Pochvy taezhnoy zony Urala i Zauralya [Soils of the taiga zone of the Urals and Trans-Urals]. Moscow, Nauka Publ., 1977. $176 \mathrm{p}$.

45. Kolesnikov B.P. Lesokhozyaystvennoe rayonirovanie i lesnoy fond. Lesa Sverdlovskoy oblasti [Forestry zoning and forest fund. Forests of the Sverdlovsk region]. Lesa SSSR [Forests of the USSR]. Moscow, Nauka Publ., 1969. Vol. 4, 250 p.

Received: 18 August 2021.

\section{Information about the authors}

Elena A. Menshikova, Cand. Sc., leading researcher, Perm State National Research University.

Tatyana I. Karavaeva, Cand. Sc., senior researcher, Perm State National Research University.

Elena A. Khayrulina, Cand. Sc., director of the Natural Science Institute, Perm State National Research University. Natalya V. Mitrakova, Cand. Sc., senior researcher, Perm State National Research University. 